6) Online Driver Model («Драйвер - онлайн-навчання») передбачає навчання он-лайн через платформу і віддалений контакт з викладачем [4-5].

Ураховуючи те, що пропоноване дослідження грунтується на викладанні психологопедагогічних дисциплін у магістратурі, коли значний обсяг навчального матеріалу припадає на самостійне опрацювання, найбільш оптимальними вважаємо поєднання та циклічне застосування таких моделей навчання, як Face-to-Face та Driver Rotation Model.

Отже, вплив на розвиток ІКК магістрантів має бути систематичним та враховувати особливості їхньої освітньої діяльності. Навчальний матеріал із психолого-педагогічних дисциплін досить різноплановий та творчий, тому у процесі навчання студентам необхідно виявляти уміння мислити, робити висновки, розв'язувати проблемні завдання, пропонувати власні варіанти дій. У поєднанні з ІКТ цей процес може стати мінливим, адже означений цикл не можна повністю інформатизувати, доцільним $\epsilon$ використання лише окремих елементів IКТ у методах, формах навчання, а також застосування певних ІКТ-засобів.

\title{
Література
}

1. Биков В. Ю. Моделі організаційних систем відкритої освіти: [монографія]. - Київ : Атіка, 2008. - 684 с. 2. Биков В. Ю. Навчальне середовище сучасних педагогічних систем // Личность в Едином образовательном пространстве: [сб. науч. статей I Междунароного образовательного форума] (г. Запорожье, 5-7 мая 2010 г.)/ под науч. ред. проф. К. Л. Крутий. - Часть 2. -Запорожье : $\quad$ ООО «ЛИПС» ЛТД, 2010. - $\quad$ С. 234-243. 3. Жалдак М. І. Інформатика - фундаментальна наукова дисципліна. Вона має вивчати закони природи, інформаційні процеси і відповідні технології / М. І. Жалдак // Комп’ютер у школі та сім’ї. - 2010. - № 2. - С. 39-43. 4. Завдання Болонської декларації [Електронний pecypc]. - Режим доступу : http://eduknigi.com/ped_view.php?id=7 5. Зимняя И. А. Ключевые компетентности как результативно-целевая основа компетентностного подхода в образовании / Ирина Алексеевна Зимняя. - Москва: Исследов. центр проблем качества подготовки специалистов, 2004. - 40 с. 6. Кліх Л. В. Становлення магістратури в системі вищої освіти України / Л. В Кліх // Науковий вісник Національного університету біоресурсів i природокористування України. Серія: Педагогіка, психологія, філософія. - 2011.Вип. 159. - Част. 3. - С. 72-79.

Інга Сіняговська

\section{ПРОБЛЕМА ІНТЕРІОРИЗАЦІЇ ЗНАНЬ У ПСИХОЛОГО-ПЕДАГОГІЧНІЙ НАУЦІ}

Сіняговська І. Ю. Проблема інтеріоризації знань у психолого-педагогічній науці.

У статті розглянуто та проаналізовано основні положення дослідження проблеми інтеріоризації знань у психолого-педагогічній науці. Окреслено основні методологічні підходи до дослідження феномену. Проаналізовано зміст понять «інтерналізація», «інтеріоризація», «інтеріоризація знань».

Ключові слова: інтерналізація, інтеріоризація, інтеріоризація знань, навчальна діяльність, методологічні підходи.

Синяговская И. Ю.Проблема интериоризации знаний в психолого-педагогической науке.

В статье рассмотрены и проанализированы основные положения исследования проблемы интериоризации знаний в психолого-педагогической науке. Обозначены основные 
методологические подходы к исследованию феномена. Проанализировано содержание понятий «интернализация», «интериоризация», «интериоризация знаний».

Ключевые слова: интернализация, интериоризация, интериоризация знаний, учебная деятельность, методологические подходы.

Siniahovska I. Yu. The problem of knowledge interiorization in the psychological and pedagogical science.

The principal concepts of interiorization in the psychological and pedagogical science are reviewed and analyzed in the article. The content of such concepts as «internalization», «interiorization», «interiorization of knowledge» is analyzed.

Key words: internalization, interiorization, interiorization of knowledge, learning activity, methodological approaches.

Звернення до проблеми виявлення сутнісного змісту поняття інтеріоризації знань у контексті його дидактичного розуміння - це реалізація спроби введення до активного тезаурусу педагогічної науки суто психологічної категорії за її походженням («інтеріоризація знань») та наповнення ії власне педагогічним (дидактичним) змістом на грунті глибинного аналізу психолого-педагогічних зв'язків між складниками, на які може бути розкладено поняття в суто психологічній та суто педагогічній площинах, а також винайдення зони перетину цих площин.

Проблема інтеріоризації знань у своєму розвитку пов'язується 3 класично традиційним питанням психолого-педагогічної науки - питанням зовнішньої та внутрішньої детермінації. У побудові теоретичних основ для розв'язання цієї задачі, як показує осмислення певних підходів, що склалися в сучасній науці, значущі переваги виявляються в концепціях розвитку особистості як особливої цілісності, що здійснюється лише за умови єдності двох процесів: зовнішнього - соціального та внутрішнього - особистісного.

Інтеріоризація як психолого-педагогічний феномен розглядається в роботах Б. Ананьєва, Н. Анікєєвої, А. Асмолова, Н. Асташової, Т. Ахутіної, В. Бехтєрева, А. Бодальова, О. Буділової, В. Буряка, Л. Виготського, П. Гальперіна, В. Давидова, I. Ільясова, Г. Ковальова, Н. Кузьміної, А. Лазурського, О. Леонтьєва, Б. Ломова, С. Максименко, В. М'ясищева, Н. Обозова, О. Петровського, М. Примуш, Л. Радзіховського, С. Рубінштейна, С. Сенющенкова, В. Сластьоніна, О. Соколової, Н. Тализіної, Д. Узнадзе, М. Ярошевського та ін.

В Українській радянській енциклопедії свого часу цей термін потрактовувався в такій редакції: (від латинського interior - внутрішній) - процес перетворення зовнішніх, реальних дій у внутрішні, ідеальні дії. Поняття «інтеріоризація» розкриває взаємозв’язок діяльності і свідомості людини, механізм оволодіння нею суспільно-історичним досвідом у процесі взаємодії з продуктами людської праці. Важливим чинником інтеріоризації є опанування мови, що також містить в узагальненій формі досвід попередніх поколінь. Інтеріоризація надає змогу людині оперувати образами предметів, які в певний момент відсутні в їі полі сприймання, думкою переміщатися в минуле, в майбутнє, у просторі тощо. Завдяки інтеріоризації зовнішні чинники людської поведінки перетворюються на усталені внутрішні якості особи. Інтеріоризація $є$ психологічним механізмом соціалізації особи (за С. Максименком).

У діяльності людини нерозривно пов'язані їі зовнішня (фізична) та внутрішня (психічна) сторони. Зовнішня сторона - рухи, за допомогою яких людина впливає на 
зовнішній світ - визначається й регулюється внутрішньою (психічною) діяльністю: мотиваційною, пізнавальною й регуляторною. 3 іншого боку, уся ця внутрішня, психічна діяльність спрямовується й контролюється зовнішньою, що відбиває властивості речей, процесів, здійснює їх цілеспрямовані перетворення, виявляє міру адекватності психічних моделей, а також ступінь збігу отриманих результатів і дій з очікуваними.

У роботах Б. Ананьєва, Н. Анікєєвої, В. Бехтєрева, А. Бодальова, Л. Виготського, Я. Коломінського, С. Кондратьєвої, О. Кузьміної, О. Лазурського, О. Леонтьєва, В. М'ясищева, Н. Обозова, О. Петровського, С. Рубінштейна закладено ідеї соціальної зумовленості розвитку людини та ії здібностей: людина у процесі засвоєння соціального середовища перетворює зовнішнє на внутрішнє, але під час цього самостійно здійснює вільний вибір зовнішніх умов власного становища. Тобто розвиток особистості як особливої цілісності можливий лише за єдності двох процесів: зовнішнього - соціального та внутрішнього - особистісного; зовнішнє перетворюється через внутрішнє, оскільки внутрішнє діє через зовнішнє.

Існує низка робіт, присвячених аналізу поняття «інтеріоризація», у тому числі роботи О. Асмолова, Т. Ахутіної, О. Буділової, П. Гальперіна, В. Давидова, І. Ільясова, Г. Ковальова,
О. Леонтьєва,
О. Петровського,
О. Пузирея,
Л. Радзіховського,
С. Рубінштейна,

О. Соколової, Н. Тализіної, М. Ярошевського та ін.

Mema cmammi: розглянути та проаналізувати основні положення дослідження проблеми інтеріоризації знань у психолого-педагогічній науці; окреслити основні методологічні підходи до дослідження феномену.

У сучасних англомовних психологічних словниках немає терміна «інтеріоризація», найближчим за значенням і звучанням $є$ поняття «інтерналізація», яке використовується й у психоаналізі. Для психоаналітиків інтеріоризація - це психічний процес або низка процесів, у яких взаємини з реальними або уявними об'єктами перетворюються у внутрішні уявлення та структури. Згадане поняття використовується для узагальненого опису процесів поглинання, інтроекції та ідентифікації, за допомогою яких міжособистісні стосунки стають внутрішньоособистими, утіленими у відповідні образи, функції, структури, конфлікти. У сучасному психоаналізі проблема інтеріоризації $\epsilon$ дискусійною (Р. Шафер, У. Мейснер, Г. Левальд та ін.). Активно обговорюється питання про те, чи є поглинання, інтроекція та ідентифікація різними ступенями, рівнями інтеріоризації, чи мають вони яку-небудь - або ієрархію, або всі ці процеси ідентичні та здійснюються паралельно один відносно іншого.

У педагогіці інтеріоризація (фр. intériorization - перехід зовнішнього у внутрішнє, лат. interior - внутрішній) розглядається як формування внутрішніх структур людської психіки за допомогою засвоєння зовнішньої соціальної діяльності, привласнення життєвого досвіду, становлення психічних функцій і розвитку в цілому. Саме тому звертаємося до актуалізації інтеріоризаційних процесів у сучасних умовах переорієнтації освітнього процесу на компетентнісній основі. Пам'ятаємо, що набуття та подальше використання досвіду $\epsilon$ невід’ємним складником структури будь-якої компетенції як кваліфікаційної вимоги та компетентності як особистісної якості.

Інтеріоризація виявляється не у простому переміщенні зовнішньої діяльності у внутрішній план свідомості, а у формуванні саме цієї свідомості. Завдяки інтеріоризації психіка людини набуває здатності оперувати образами предметів, що в цей час відсутні в полі її посиленої уваги.

У Великому психологічному словнику «інтеріоризація» розглядається як психологічне явище, що означає формування стабільних структурно-функціональних 
одиниць свідомості через засвоєння зовнішніх дій з предметами й оволодіння зовнішніми знаковими засобами (наприклад, формування внутрішнього мовлення із зовнішнього мовлення) [1, с. 206].

О. Петровський, М. Ярошевський визначають поняття інтеріоризації через формування внутрішніх структур людської психіки завдяки засвоєнню структур зовнішньої соціальної діяльності. Аналогічні визначення поняття «інтеріоризація» як формування структур людської психіки завдяки засвоєнню структур зовнішньої соціальної діяльності знаходимо й в інших словниках [5].

Термін «інтеріоризація» використовується представниками різних напрямів і шкіл у психології - згідно з їх розумінням механізмів розвитку психіки.

Термін «інтеріоризація» використовується й як синонім інтроекції (Ж. Лапланш, Ж.-Б. Понталис). У більш вузькому сенсі - це процес, за допомогою якого міжособистісні стосунки перетворюються на внутрішньо-особистісні (інтеріоризація конфлікту, заборони тощо). Це поняття часто використовується у психоаналізі. Зазвичай воно осмислюється в контексті поняття інтроекції, тобто фантазматичного переходу від об'єкта - «доброго» чи «поганого», цілісного або часткового - усередину об'єкта. Цей процес припускає структурне розчленовування психіки, що дає змогу пережити ці відносини й конфлікти на внутрішньопсихічному рівні.

Поняття, що збігаються з інтеріоризацією, використовуються у психоаналізі під час пояснення того, яким чином в онтогенезі й філогенезі під впливом структури міжіндивідуальних відносин, що переходять «усередину» психіки, формується структура несвідомого (індивідуального або колективного), що визначає у свою чергу структуру свідомості.

Поняття «інтеріоризація» було введено до наукового обігу представниками французької соціологічної школи (Е. Дюркгейм та ін.).

У роботах Е. Дюркгейма інтеріоризацію було представлено як процес, коли дитина запозичує в громадської свідомості поняття, уявлення, категорії, що потім утворюють структуру її власних поглядів.

Поняття «інтеріоризація» у французькій соціологічній школі було пов’язано 3 поняттям соціалізації й означало запозичення основних категорій індивідуальної свідомості зі сфери громадських уявлень; перенесення громадської свідомості в індивідуальну, завдяки чому змінювалося місцезнаходження, але не природа уявлення. У близькому значенні воно використовувалось французькими психологами П. Жане, Ж. Піаже, А. Валлоном та ін.

Першим психологом, який розглядав інтеріоризацію як психологічний принцип, був П'єр Жане. Поняття «інтеріоризація» означало прищеплення елементів ідеології до споконвічно біологічної свідомості індивіда: ідеологія, громадська свідомість переносилось в індивідуальну свідомість; змінювалось місцезнаходження, але не природа уявлення; воно як було, так і залишалося ідеальним.

Концепція французької соціологічної школи, як зазначає С. Сенющенков, дійсно, є однією з перших, у якій детально опрацьовується проблематика соціальної детермінації, але ii представники не використовували термін «інтеріоризація» й не запроваджували спеціального термінологічного визначення цього процесу. Причиною переносу на концепцію французької соціологічної школи терміна «інтеріоризація» в такому випадку може поставати лише широке розуміння інтеріоризації як механізму соціальної детермінації особистості взагалі.

Ж. Піаже у своїй операціональній теорії розвитку інтелекту підкреслював роль 
інтеріоризації в утворенні операцій, поєднанні узагальнених і скорочених, взаємозворотних дій. У плані сприйняття, у полі зовнішніх предметів кожна дія спрямовується лише на власний результат, вона виключає одночасне протилежне. Лише в ідеальному уявленні можна збудувати схему двох таких дій і вивести з їх взаємозгасаючих результатів «принцип збереження» основних якостей речей, основні константи предметного всесвіту.

Водночас утворення такого внутрішнього плану не становило в теорії Ж. Піаже самостійної проблеми, але було природним наслідком розвитку мислення. Для Ж. Піаже інтеріоризація - явище вторинне від логічного розвитку мислення й означає створення плану ідеальних, власне логічних конструкцій. Питання про перехід від непсихічного до психічного при цьому не порушувалося. В аналогічному смислі інтеріоризацію розуміли представники символічного інтеракціонізму.

Поняття інтеріоризації займало свого часу важливе місце в системі понять багатьох радянських психологічних теорій, а саме:

- проблема об'єктивного методу психологічного дослідження;

- проблема соціальної детермінації психіки людини;

- психофізична проблема (у сучасному потрактуванні - проблема природи й походження психічного), що актуальні в сучасній психології.

Саме тому ми звертаємося до вивчення поняття інтеріоризації - робимо спробу уточнити його зміст й розмежувати різноманітні визначення терміна, зіставляємо теоретичні положення й емпіричні дані, виявляємо зв'язки цього поняття 3 іншими поняттями, перспективи його застосування для розв'язання сучасних теоретичних питань психодидактики. При цьому, як зазначає С. Сенющенков, історико-психологічне дослідження джерел i рушійних сил розвитку поняття інтеріоризації уможливлює встановлення зв'язків між різними поняттями інтеріоризації, виявлення причини існуючої варіативності поняття.

У східнослов'янській психології процес інтеріоризації розуміється як перетворення структури предметної діяльності у структуру внутрішнього плану свідомості. Велика група науковців (Л. Виготський, П. Гальперін, О. Леонтьєв) відповідала словом «інтеріоризація» на питання: яким чином у ході онтогенетичного розвитку формуються соціальні механізми психіки людини? Змістовно сам процес інтеріоризації ці науковці розуміли багато в чому порізному. Позиції дослідників 3 проблем інтеріоризації критично оцінювали О. Брушлинський, Б. Ломов, С. Рубінштейн.

Принципового значення поняття «інтеріоризація» набуло в культурно-історичній теорії Л. Виготського, де воно розглядається як перетворення зовнішньої предметної діяльності на структуру внутрішнього плану свідомості. При цьому Л. Виготський переважно користувався терміном «врощення» (синонім інтеріоризації), що розуміється як перетворення зовнішніх засобів і способів діяльності на внутрішні, розвиток внутрішньо опосередкованих дій із дій зовнішньо опосередкованих. На його думку, будь-яка людська форма психіки спочатку складається як зовнішня соціальна форма спілкування між людьми, як трудова діяльність чи інша діяльність, і лише потім, у результаті інтеріоризації стає компонентом психіки окремого індивіда. Саме в цьому переході від зовнішніх, розгорнутих, колективних форм діяльності до внутрішніх, згорнутих, індивідуальних форм ії виконання, тобто у процесі інтеріоризації, перетворення інтерпсихічного в інтрапсихічне відбувається психічний розвиток людини.

Власне твердження Л. Виготського: вищі психічні функції спочатку утворюються як 
зовнішні форми діяльності й лише згодом, у результаті інтеріоризації, стають психічними процесами індивіда, - не може не звучати як твердження, що принаймні в такому випадку (вищих психічних функцій), непсихічне перетворюється на психічне. Принципове значення цього є очевидним: трохи відкривається можливість подолання одвічної прірви між ними.

Л. Виготський розумів спілкування лише як вербальне, точніше - спілкування свідомостей. Такий підхід був притаманний школі Е. Дюркгейма (лише пізній Ж. Піаже багато в чому подолав його у своїй концепції сенсомоторного інтелекту).

У XX столітті ця точка зору отримала найбільш поширений розвиток у різних варіаціях: у так званій лінгвістичній філософії, у філософії Е. Кассирера, де людина визначається як «тварина, що створює символи», у гіпотезі «лінгвістичної відносності» Е. Сепіра - Б. Уорфа та ін. Філософські висновки 3 цих концепцій - конвенціоналізм, релятивізм, агностицизм, не були притаманними Л. Виготському, але конкретно протипоставити що-небудь цій точці зору він не міг. За це його справедливо критикували його учні (П. Гальперін, П. Зінченко, О. Леонтьєв) та інші психологи (О. Брушлинський, С. Рубінштейн).

О. Леонтьєв у своїх працях конкретизував і розвинув низку положень Л. Виготського. У своїх роботах О. Леонтьєв послідовно відстоює думку про те, що принципове й ключове значення для розуміння розвитку психіки дитини має вивчення процесу перетворення його зовнішньої сумісної діяльності на індивідуальну, що регулюється внутрішніми утвореннями, тобто вивчення інтеріоризації сумісної діяльності й пов'язаних з нею психічних функцій.

Необхідність інтеріоризації визначається, на думку О. Леонтьєва, тим, що центральний зміст розвитку дитини - це привласнення нею досягнень історичного розвитку людства, які спочатку постають у формі зовнішніх предметів і зовнішніх словесних знань. Їх специфічне суспільне значення дитина може відобразити у своїй свідомості лише шляхом здійснення по відношенню до них діяльності, адекватній тій, що в них утілена й опредмечена. Дитина самостійно не може виробити й виконати цю діяльність. Вона завжди повинна будуватися оточуючими людьми у взаємодії й спілкуванні 3 дитиною, тобто у зовнішній сумісній діяльності, у якій розгорнуто представлені дії. Їх виконання дає змогу дитині привласнити пов'язані з ними значення. У подальшому самостійне просування думки дитини можливе лише на основі вже інтеріоризованного історичного досвіду.

Таке розуміння сутності інтеріоризації внутрішньо пов'язане 3 теорією розвитку психіки людини, згідно з якою цей розвиток відбувається не через вияв вродженої й спадкової видової поведінки, не через її пристосування до мінливого середовища, а шляхом привласнення індивідами досягнень людської культури.

Ці положення О. Леонтьєва слугують суттєвою конкретизацією загального генетичного закону психічного розвитку дитини, що був сформульований Л. Виготським [2].

О. Леонтьєв розглядав питання про співвідношення інтеріоризації з пам'яттю. Він принципово відокремлював засвоєння суспільно-історичного досвіду від засвоєння будь-якої іншої інформації.

Ці теоретичні побудови О. Леонтьєва отримали конкретно-психологічне відображення в розумінні процесів навчання та виховання. На думку О. Леонтьєва, для побудови в дитини мисленнєвої дії спочатку ії зміст потрібно дати в зовнішній предметній (або екстеріоризованій) формі, а далі шляхом їі перетворення, узагальнення і скорочення за допомогою мовлення (тобто шляхом інтеріоризації) перетворити цю дію у власне розумову.

Іншими словами, знання можуть бути повноцінно засвоєні дитиною лише під час виконання нею певних предметних і розумових дій, що спеціально в неї формуються. 
Одночасно у ході здійснення дій, що спрямовані на розв'язання визначених задач, людина оволодіває не лише конкретними знаннями, але й відповідними психічними здібностями й засобами поведінки. У цьому й полягає основна ідея діяльнісного підходу до процесів навчання та виховання.

Згідно з позицією О. Леонтьєва, будь-яке поняття є продуктом діяльності, саме тому поняття не може бути передане тому, хто навчається, йому неможливо навчити. Але можливо організувати, побудувати адекватну поняттю «діяльність». Передумови інтеріоризації - це неусвідомлений внутрішній план (у дитини в ранньому онтогенезі). У результаті інтеріоризації цей внутрішній план якісно змінюється - формується план свідомості [4, с. 117].

Розроблена П. Гальперіним теорія планомірно-поетапного формування розумових дій і понять $є$ фактично теорією інтеріоризації. Найважливіше місце в цій теорії займає вчення про орієнтовну основу дій, що складає головну структурну одиницю діяльності людини.

П. Гальперін виокремлює в дії дві основні частини: орієнтовну й виконавчу. Похідною від них є контрольно-корекційна частина. У теорії П. Гальперіна орієнтовна частина дії займає провідне місце. Зовнішні дії ніколи цілком у внутрішній план не переносяться. Інтеріоризації підлягає лише їх орієнтовна частина. На думку П. Гальперіна, спочатку розгорнута матеріальна дія у процесі інтеріоризації узагальнюється, скорочується й на заключній стадії (в розумовому плані) набуває характеру психічного процесу [3].

Дослідження П. Гальперіна змінили уявлення про природу «внутрішнього плану» і процесу інтеріоризації: йому вдалося показати, що розумовий план - не порожній посуд, у який щось вміщується, розумовий план утворюється, формується в ході й результаті інтеріоризації.

Різноманітність визначень і концепцій свідчить про неоднозначність підходів до терміна «інтеріоризація».

Аналіз різних наукових підходів до визначення терміна «інтеріоризація» показав, що результатом цього процесу $є$ не просто набуття нових знань, а перетворення структури особистості.

Отже, між цими розглянутими психологічними концепціями існують не суперечності, а відмінності, не змістовні розходження, а аналіз різних аспектів складного явища інтеріоризації. Це свідчить про неоднозначність поняття «інтеріоризація» у психологопедагогічній науці. Проте термінологічна складність не заважає розробленню багаточисельних психолого-педагогічних досліджень з опорою на механізми інтеріоризації. Недостатній стан розробки досліджуваної проблеми і iï теоретико-методологічного обгрунтування, а також потреба в розробленні ефективних механізмів іiі реалізації відкривають перспективи подальшого розроблення окресленої проблеми - виявлення сутнісного змісту поняття інтеріоризації знань у контексті його дидактичного розуміння.

\section{Література}

1. Большой психологический словарь / под ред. Б. Г. Мещерякова, В. П. Зинченко. Санкт-Петербург, 2003. - 672 с. 2. Выготский Л. С. Собрание сочинений. Т. 2./ Лев Семенович Выготский. - Москва, 1982. - 504 с. З. Гальперин П. Я. Введение в психологию: [учебное пособие для вузов]/ Петр Яковлевич Гальперин. - Москва : Книжный дом «Университет», 1999. - 332 с. 4. Петровский А. В. Основы теоретической психологии / Артур Владимирович Петровский, Михаил Григорьевич Ярошевский. Москва: ИНФРА-М, 1999. - 528 с. 5. Психология развития. Словарь / под общей ред. А. В. Петровского, редактор-составитель Л. А. Карпенко. - Москва : ПЭР СЭ, 2005. - 176 с. 